Александра В. Чебашек ${ }^{1}$

https://doi.org/10.46630/phm.13.2021.14

Универзитет у Крагујевцу

Филолошко-уметнички факултет

Центар за проучавање језика и књижевности

\title{
МЕХАНИЗМИ ПРЕГОВОРА СА ГУБИТКОМ: ТРАУМА МРТВЕ ДРАГЕ У ГАВРАНУ И МОРЕЛИ ЕДГАРА АЛАНА ПОА И У РОМАНУ САБО ЈЕ СТАО ОТА ХОРВАТА
}

\begin{abstract}
Заједничка нит која повезује Морелу и Гаврана Едгара Алана Поа и роман Сабо је стао аутора Ота Хорвата јесте тематизација мртве драге која је основ трауме све тројице јунака. Најпре, у раду ће бити речи о трауми као психичком стању, потом ћемо указати на мотив мртве драге који је један истовремено један од најлепших и најтрагичнијих мотива у књижевном стварању. Рад ће се бавити преиспитивањем трауматских и посттрауматских стања субјеката, односно, истраживаће који и какви механизми преговора са губитком у поменутим делима постоје, у коју сврху служе и да ли субјектима омогућавају избављење из трауме. Дакле, указаћемо да ли је и на који начин у поменутим делима могуће превазилажење трауме. Мртве драге - Ленора, Морела и А. - различито су приказане и на различите начине је тематизована њихова смрт. Субјекти на све могуће начине мртве драге настоје да одрже живим макар у тексту, макар дискурзивно, макар у сећању. Циљ је указати и на принципе функционисања (и покушаја превазилажења) трауме од најблажег примера, Гаврана, до најекстремнијег, романа Сабо је стао у ком је субјект са траумом постао сасвим саживљен. Морела ће нам, поред тематизације мртве драге, послужити и као пример како погубно и трагично по субјекат могу деловати непревазиђене трауме услед њиховог нагомилавања.
\end{abstract}

Кључне речи: мртва драга, траума, Гавран, Морела, Едгар Алан По, Сабо је стао, Ото Хорват, механизми преговора, психоанализа

\section{1. Увод}

Заједничка нит одабраног корпуса јесте тематизација мртве драге услед трауматског искуства губитка вољене особе. Препозната вечита жеђ за љубављу онда када објект љубави премине, очајнички жели да се оживи од стране субјекта у некоме/нечему другом. У Поовој Морели то је

1 aleksandra.cebasek@filum.kg.ac.rs 
учињено рађањем девојчице док је у Гаврану мртва драга присутна кроз прижељкивање да су она и њен дух ту, присутни. У роману Сабо је стао, траума мртве драге сам је наратив. У поменутим делима, љубавни односи саткани су од претераности која води апсолутном поистовећивању вољене, мртве драге, и субјек(а)та. Прихватање смрти вољене особе пропраћено је специфичним механизмима уз помоћ којих субјекти покушавају да превазиђу своје трауматско стање, али некада сасвим несвесно, тим истим механизмима подривају чињеницу да је драга мртва настојећи да је на ма који начин отелотворе крај себе.

\section{2. Траума као психичко стање и механизми преговора}

Стање настало након тешких душевних и емотивних потреса назива се трауматична неуроза и може бити „једнака хистерији, али је редовно превазилази јако израженим знаковима субјективне патње (по чему је врло слична, рецимо, хипохондрији или меланхолији), а и знаковима много изразитије опште слабости и душевног растројства" (FROJD 2006а: 12). Кали Тал истиче да трауму може изазвати „плејада животних искустава, али и конкретни догађај, дуготрајна изложеност опасности, али и изненадни бљесак страха, репетитивни образац злостављања, али и један напад, период слабљења и трошења, али и тренутак шока" (KALI TAL 1996: 457 према MATOVIĆ 2020: 84). Траума је, дакле, врста психичког процеса са истакнутим положајем субјекта који је њен носилац (и темељ). Срж трауматске неурозе фиксирана је на конкретни тренутак трауматичне несреће (уп. FROJD 2006b: 208), односно, на доживљај који је изазвао исувише јака осећања.

Траума као својство субјективитета може бити уплетена у дискурс и његова просторно-асоцијативна и темпорална својства, у наратив и у сећање (уп. MATOVIĆ 2020: 84). Дискурс нуди погодно тло трауматских истраживања на основу уочених механизама који се појављују као обавезни приликом (покушаја) превазилажења личне трауме. То значи да је адекватним читањем дискурса могуће указати на који начин механизми превазилажења трауме функционишу, у којој мери су они срасли са субјектом и на који начин доприносе успостављању фигуре мртве драге. Осим што механизми служе за преговоре са губитком, они служе и у одбрамбене сврхе - њима се од трауме бежи у циљу заштите сопственог интегритета. Борба између ових механизама својствена је главним ликовима нашег корупуса. Кад нам се учини да траума превазиђена, да је смрт драге прихваћена, они нам покажу да је много теже него што изгледа. Траума је константа и тешко ју је превазићи.

Уочени механизми попут ретроспективе, прихватања, порицања, наде, ишчекивања, именовања важни су за јунаке јер доприносе пре- 
вазилажењу трауме губитка и прихватању реалности. Међутим, механизми не фунционишу увек прогресивно. Они могу бити и регресивни. То значи да субјект, јунак, служећи се својим механизмима превазилажења туге, боли, смрти, свега онога што трауму чини, каткад се поврати још дубље у њу. Не намерно и не случајно. Механизми превазилажења не помажу увек у помирењу са, у нашем случају, губитком вољене особе, они некад доведу до још јачег унутрашњег потреса. Но, они су субјекту неопходни јер пружају могућност избављења и излечења.

Што се нашег корпуса тиче, механизми делују тако да колико год постојала свест о смрти вољене, субјекти наменски мртву драгу рекреирају изнова и изнова - Сабо то чини наративом о њој², јунак у Поовој Морели око мртве драге испреда реинкарнирајућу приповест док јунак у Гаврану (жели да) осећа присуство „духа” Леноре иако њене конкретне појаве у самом тексту нема. Та поновна, назовимо разним именима, рекреација, репродукција, ретроспектива, реконструкција мртвих драга неоспорно је потребна и као механизам преговора са губитком и као етапа у прихватању стварности.

\section{3. Фигура мртве драге - тематизација у књижевности}

Фигура мртве драге као средиште конструисања приповедачког текста своје реализације има у многим делима светске и српске књижевности. У неку руку, то је непресушни мотив из кога аутор може црпети толико тога - од најдивнијег до најморбиднијег. Слободан Владушић (2009: 16) говорећи о античком миту о Орфеју и Еуридици, миту кроз који је транспонована сва дубина памћења која се тиче мотива мртве драге, указује на два могућа читања мотива мртве драге: мотив мртве драге може бити тематска илустрација жеље за синтезом (мртва драга се указује као визија са јасним и препознатљивим обрисима и њена је моћ да визију централизује и позиционира субјект који визију перципира - „тиме се ствара привид поновног сједињавања песничког субјекта са мртвом драгом” (VLADUŠIĆ 2009: 17). Са друге стране, тематизација мотива мртве драге може бити она у којој се субјект не заварава у погледу одвојености од мртве драге (уп. VLADUŠIĆ 2009: 17) док субјект наставља да је опева, односно, да о њој пише. Овај други тип тематизације мртве драге заправо је „хиперболизовано сећање на мртву драгу” (VLADUŠIĆ 2009: 18) док ће услед дезинтеграције овог типа тематизације мртве драге субјект морати да се суочи са проблемом заборава као и са проблемом сећања и успоме-

2 У роману Сабо је стао, најадекватније и најпотпуније су изложени механизми преговора управо због апсолутне приповедачке отворености субјекта, Сабоа. Разлог томе је сама структура романа који је вид записа са психотерапијских сеанси унутар којих субјект од својих механизама не може да побегне већ је намерно усмерен на њих. 
на. Закључимо, тематизација мотива мртве драге може имати симболичку структуру (мртва драга се појављује као визија) и алегоричну струкутуру (мртва драга је објект продуженог сећања субјекта - хиперсећања) (уп. VLADUŠIĆ 2009: 317).

Свака смрт остаје у сећању, све је сећање: „сећање преокреће оно што се не може обрнути и враћа оно што је изгубљено” (ASMAN 1999: 127). Конструисаност процеса сећања у нашем примеру условљена је проживљеном траумом која се рефлектује писањем, наративом, приповедањем као посттраумаским видом утехе. Потреба и потрага за утешним наративом неопходна је како би се остварила идентификација субјеката са самим собом, а та идентификација најделотворнији је механизам премошћавања трауме. Одабрана књижевна дела су реконфигурације наративних идентитета путем (при)сећања, али су и сурово сусретање са трауматским стањем, са смрћу драге. Уколико су перцепција и сећање квалитативно другачији процеси (уп. BERGSON 1927: 67-71), они се у нашем случају међусобно условљавају. То најбоље илуструје роман Сабо је стао јер Саша Сабо, главни јунак, стрепи да му сећање на њу у прошлости (и смрти) не наруши перцепцију ње коју има сад и коју настоји да задржи. Сабо прича причу како би створио вечно сећање на мртву драгу, али вечно је тако дискутабилна реч и ни у једном од поменутих дела нема своје утемељење. Вечно је варијабилно. Вечни су само доживљаји смрти, а мртве драге непобитно подлежу времену, забораву и промењеној перцепцији. Поента је да актуелна конфигурација идентитета субјек(а)та условљена траумом неоспорно утиче на метаморфозу перцепције у сећање, не изводи статичност садашњег тренутка - све (п) остаје сећање.

\section{1. Едгар Алан По, Гавран}

Преговори са траумом: гавран као психотерапеут

Истакли смо већ да субјект трауму мртве драге може наративно доживети двоструко - дакле, може је тематизовати као визију чију појаву пропраћују јасни елементи ње док са друге стране, субјект мртву драгу може тематизовати кроз наративизацију сећања и успомена. У Гаврану, мртва драга, Ленора, првобитно се „појављује” као звучна илузија коју субјект прижељкује, а до чије визуелизације и реалне појаве не долази. Субјект Гаврана би на први поглед припадао групи тематизације мртве драге у којој се тежи за синтезом. Ипак, до тематизације мртве драге као визије са јасним и препознатљивим обрисима не долази, већ субјект Гаврана само прижељкује да до те визије, појаве и њеног куцања на прозору дође.

Поеми претходи трауматична смрт драге те субјект Гаврана 
услед (пост)трауматског шока за прву неочекивану посету/појаву помишља да је Ленора. Тај механизам (узалудног) ишчекивања преминуле својствена је његовом трауматском стању. Чак и ситница која би могла бити потенцијално објављивање/појављивање ње, у јунаку изазива лавину осећања, питања, емоција. То је показатељ да траума није превазиђена и да је сваким делом везана за Ленору. Сада је јасније да је субјект тај који жели да оствари синтезу са мртвом драгом, макар она била ирационална и онострана. Та скривена нада у поновну појаву ње видљива је уколико се присетимо речи Поовог јунака упућених мрклом мраку:

„Тек реч једну чух из мрака, чух „Ленора!“ тад најтише.

То ја шапнух реч „Ленора“ коју одјек врати тише само то и ништа више.” (РО 2006а: 41)

Именовање преминуле нужно је јер позивањем мртве драге, субјект схвата да одазива нема, да она није тај посетилац, тиме је у исти мах именовао и своју наду и своје разочарење. Дакле, именовање Леноре је било потребно да би дошло и до извесног прихватања њеног неповратка. Већ у следећој строфи, након удараца по прозору неће помислити да је можда Ленора, већ ће рећи: „то ветар је, ништа више” (РО 2006а: 41). Тиме је уочен плодоносан механизам премошћавања трауме (и туге) у Гаврану, а то је именовање трауме. Сусрет са трауматичним психичким догађајем, превазилажење трауме и саму стварност учинила је привремено прихватљивијом: не куца мртва драга већ је могуће да је то само ветар. Тај механизам потајног надања у њену присутност резултирао је разочарењем и изневерованим очекивањем. Уместо драге, гавран. И то гавран који настоји да буде алегоријско разрешење напетости у субјекту (уп. VLADUŠIĆ 2009: 46, 47). Према Шевалијеу и Гербрану (2004: 228), гавран може бити и симбол самоће, односно, симбол својевољног осамљивања, као и једно од обележја наде ,јер непрекидно понавља: cras, cras, тј. сутра, сутра".

Разочаран јер то ипак није његова драга већ гавран, лирски субјект своју борбу са траумом подиже на виши ниво: обраћа се тишини, обраћа се мраку ословљавајући га као живо биће - мраку говори: Леноpa!. Унутрашња као и просторна празнина ${ }^{3}$ погубне су по субјекта Гаврана те је зато и потребан известан отклон од константне тишине са којом је субјект срастао. Мрак и лице субјекта стоје једно наспрам другог. То је слика потпуне празнине - и унутрашње и спољашње. Лирски субјект простор у коме тренутно борави назива местом свог неспокоја (уп. РО 2006а: 42). Зато долази до вештачког испуњавања простора сопственим

3 Простор је доживљен као уклет: „Склоних капке те уклете и кроз прозор тад улете отмен Гавран” (РО 2006: 42). 
речима - драге нема, њених речи нема, празнине има. Чак и оно што је по својој природи нечујно, неосетљиво и несазнатљиво - мрак, тишина, мир - лирски субјект осећа: ,ал〉 тишина беше јака, нит мир даде каквог знака" (РО 2006а: 41). Само једном речју лирски субјект испуњава мрак, испуњава празнину, испуњава простор - Ленора! - речју која му се изнова враћа у виду одјека.

Празнина простора и бића се испуњава речима, питањима и одговорима. Захваљујући њима и интервенцији гаврана, мртва драга се у субјектовом животу утемељује као коначно мртва. Не куца драга већ гавран, не говори драга већ гавран, ту није драга већ гавран, је ли могући поновни спој са мртвом драгом, „никада више”, каже гавран. То значи да гавранове речи конотативно одговарају не само његовим питањима већ одговарају и његовој нади у могуће виђење мртве драге - дакле, никад више. Намерна љубавникова питања су изазвана „људском жеђи за самомучењем” да би се гаврановим одговорима „никад више” доспело до највишег сладострашћа боли (уп. РО 2006b: 81) које је неоспорно повезано са превазилажењем трауме мртве драге. На тај начин, гаврана можемо посматрати као исцелитеља који је тексту и субјекту потребан ради превазилажења трауме јер покретањем питања која га муче и добијеним оштрим и суровим гаврановим одговорима, стварност постаје субјекту тешка, али прихватљивија. На први поглед, гавран подсећа на особу којој се душа исповеда. Исто тако, чини се да гавран има очигледан терапијски утицај на психичко стање Поовог јунака јер доприноси и мирењу са смрћу Леноре 4 . Гавран наводи јунака да именује своју трауму да би изнова прошао кроз стање нелагодности, наводи га да изговори оно неизрециво док га са друге стране кратким одговором „Никад више“ освешћује. Сурово, али потребно и учинковито јер субјект ће рећи: „где анђели насмешену, једину Ленору скрише? Ту имена нема вище ““ (РО 2006а: 39). Његова реченица да имена нема више може се протумачити као успешно деловање гавранових речи: њено одсуство је прихваћено, субјект изговара (и схвата) да ни имена нема као што ни ње нема више. Дакле, гавранова улога је посредничка, кроз њу субјект доживљава свест о смрти (уп. VLADUŠIĆ 2009: 47):

„да бих све то одгонетн'о, ја наслоних главу сетно док се светлост загонетно на наслона лила плишне, али она у том светлу на наслоне ове плишне неће лећ, ах, никад више!” (РО 2006а: 45).

4 Гавран душу субјекта испуњава смешком (РО 2006а: 42). Нагласићемо да је гавран одговоран за сва расположења субјекта у поеми: од узнемирености, разочарења, сете, туге, боли до осмеха.

5 Италик, А. Ч. 
Јунак постаје свестан да је њена поновна појава дефинитивно немогућа. Чини се да је гавран попут помагала који се савршено уклапа у улогу психотерапеута који субјекту помаже да именује, прихвати и (покуша да) превазиђе своју трауму.

Ако гаврана схватимо као оног ко отвара истине субјекту и нагони га да их прихвати, постаје јасно да је у превазилажењу трауме услед смрти драге најважније то прихватање сурових истина: нема заборава, нема Леноре, не може се без сећања на њу, нема лека болима, нема поновног сусрета, нема повратка ње никад више. Гавран као метафорична замена мртве драге јунаку доноси откривење и прихватање тешких истина, а једино је то прихватање прави пут ка премошћавању трауме.

\section{2. Едгар Алан По, Морела}

Морела или Мореле - је ли могуће превазилажење трауме када се траума калеми на трауми?

У Поовој приповеци Морела, одмах је указано на чудни однос љубавника и на његове „чудне наклоности” (РО 1996: 216) које је гајио према својој пријатељищи ${ }^{6}$ Морели. Тај однос био је специфичне природе „моја је душа, од првог нашег састанка, планула огњем [...], али тај огањ није био огањ љубави." (РО 1996: 216) већ га је она једноставно чинила срећним. Морела је била необично учена и интелигентна жена. Заједно су били препуштени чарима (мистичне) науке којој је Морела била водиља.

Пресудни тренутак о коме субјект говори јесте Морелино полако одумирање - прсти су постали бледи, глас све тиши, блесак очију све тужнији, црвене пеге су прекриле образе, плаве жиле су искочиле на челу - супруг је сасвим био свестан њеног физичког постепеног умирања. Међутим, полако се у приповетку увлачи нови мотив, долази до, како он каже, „поступног хлађења љубави““ (уп. РО 1996: 218) које је очигледно било повезано са губитком њеног животног елана, са пропадањем њене физичке естетике, динамике, са постепеним губитком сјаја њених умних очију. О нарушеном љубавном односу и његовом неприродном одношењу према њеној смрти сведоче и следеће речи:

„Треба ли онда да кажем да сам прижељкивао са озбиљном и жарком жељом час Морелине смрти? Да, прижељкивао сам; [...] постао сам бесан због одлагања и крвничким срцем проклињао дане, часове и горке тренутке који су, изгледало је, бивали све дужи и дужи што се њен

6 Италик, А. Ч.

7 Испоставиће да је Морела то знала: „Није било дана када си ме волео [...] али обожаваћеш кад умре она које си се грозио за живота." (РО 1996: 219). 
нежни живот више гасио, као сенке при смирају дана.” (РО 1996: 218)

Ове речи можемо разумети као сажаљење због пропадања и боли коју смрт доноси, као призивање те смрти зарад престанка Морелиног мучења, али одвише се чини неприродним супругово ишчекивање смрти које се коси са прижељкивањем ње 8 што пре. Ако је смрт драге прижељкивана и очекивана, онда можемо мислити о извесној супруговој психичкој припремљености за тај тренутак која у трену бива разрушена Морелиним речима: „Још једном ти кажем, ја умирем. Али у мени је залога оне љубави - ах, тако мале - коју си осећао према мени, према Морели. И кад моја душа оде, дете ће живети - твоје дете и моје, Морелино." (РО 1996: 219). Могуће је да њена смрт којој се надао у њему не би изазвала никакав трауматски потрес, али изненадна промена околности условљена појавом детета које на свет долази онога трена када драга умире, у субјекту неминовно изазива додатно интензивиран трауматски шок који је фактички изазван двема различитим траумама: траумом смрти мртве драге у непредвидивим околностима и траумом узрокованом рођењем детета за чије постојање није знао, а одсад припада само њему.

Морела супругу, осим детета, оставља својеврсно пророчанство, ако не и клетву: „Али твоји дани биће дани туге, оне туге која је постојанија од свих осећања [...] Јер, часови твоје среће су минули, а радост се не бере два пута у животу, као руже што двапут цветају." (РО 1996: 219). Те Морелине речи изазивају унутрашњи потрес. Клетва ће подсвесно наставити да га прати те ово може бити разлог због ког супруг одбија да именује дете. Потискивањем и једне и друге трауме, субјект свој емоционални и психички свет додатно оптерећује поменутим речима иако ми то у тексту не видимо експлицитно, али препознајемо по његовом понашању према девојчици. Потискивање ове клетве/пророчанства указује на страх од обистињавања, али субјект ни једног трена не увиђа чињеницу да је он тај који обистињавању Морелиних речи доприноси и то на сасвим психички перфидан, посттрауматски начин. Субјект није превазишао трауму смрти Мореле него се појавом детета само надовезао на већ постојећу трауму. Поов јунак и рођење детета доживљава трауматично јер је то рођење пропраћено кобним речима. Траума мртве драге и траума због новорођеног детета су потковане Морелином клетвом која отвара простор такозваној вечној трауми: пророчанство о вечној туги и несрећи стоји изнад рођеног детета и преминуле жене, стоји као ужас од ког субјект жели да побегне, али му се упорно враћа.

Да је тако, јасно је када уочимо да супруг свој живот проводи у туговању и немиру предосећајући у себи Морелине претпоставке. Вре8 Ако је Морела била свесна његовог хлађења љубави према њој и знала је разлог томе (уп. РО 1996: 218), не смемо одбацити чињеницу да је Морела можда и увидела његово потајно прижељкивање њене смрти. 
меном, субјект почиње да се служи механизмом поистовећивања. Отац у девојчици види „савршену слику оне која је умрла” (РО 1996: 219), у њој препознаје све оне особине које су биле Морелине. Због њене клетве, субјект је у константном трауматском шоку јер свет настоји да перципира у складу са речима које су му изречене. Са друге стране, непревазиђена траума испољава се на однос са кћерком, реч је о помереној перцепцији оца који наместо неименоване кћерке све време пројицира мртву драгу препознајући у њој Морелу.

Говорећи о трауматичној неурози, Фројд (2006а: 12-20) скреће пажњу како приликом трауматског искуства, ум функционише тако што предмет/појаву/догађај непријатности опристуњава као предмет свог сећања и психичке обраде. Субјект Мореле настоји да оприсутни мртву драгу по сваку цену механизмом поистовећивања, односно, упоређивања. Отац девојчице сваки сегмент мртве драге види у својој кћерки: од лица, осмеха, очију, гласа, чела, прстију па све до израза и реченица, у свему види мртву Морелу. Субјект је услед потиснутих траума пројицирао свој тренутак трауме (смрт Мореле) на своје дете. Нама нису познате истинске особености детета јер сваки говор о неименованој и некрштеној ћерки сведен је на поређење са мртвом мајком и на утискивање Морелиних особина на девојчицу. На тај начин, субјект очигледно настоји да оприсутни предмет своје трауме у буквалном смислу.

Девојчица је живела у потпуној унутрашњој осамљености без контакта са спољашњим светом. Након пар година, отац жели да крсти девојчицу је му се чинило да би се обредом крштења ослободио ужаса своје судбине (уп. РО 1996: 221). Након што је рекао како је „Морелино име умрло са њом.” и како „никад кћери нисам говорио о мајци; било ми је немогуће” (РО 1996: 220), отац на крштењу чини парадоксалну ствар. Када је требало над крстионицом изрећи име, отац ће, узнемирен, све-

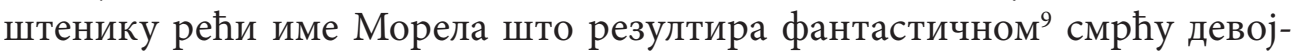
чице. Речи „Ево ме!” (РО 1996: 221), осим што можемо посматрати у логичном кључу обећане поновне објаве преминуле драге, Мореле, можемо размотрити и са психоаналитичког аспекта који подразумева следећу претпоставку: након трауматског догађаја, даље потискивање трауме лоше је по психичко стање субјекта јер неминовно доводи до дисбаланса психе и несвесног умножавања трауматских стања, а то се, као што видимо, даље транспонује на његов доживљај света око себе. Стога, по-

9 Смрт девојчице наступа изрицањем речи: „Ево ме!” (РО 1996: 221) што се може схватити као поновна појава, као реинкарнација мртве Мореле. Том закључку доприноси и крај приповетке, одн. тренутак када у гробници не буде ни трага од мајке Мореле док отац сахрањује кћерку Морелу. Због своје комплексности, истраживање нећемо фокусирати на фантастичне и мистичне аспекте Поових дела. Циљ је указати на низање траума и позицију субјекта у покушају превазилажења трауматских стања. 
тискивање и непревазилажење трауме неминовно доводи до овога „Ево ме!” односно, до поновног и још јачег трауматског таласа. Зато поменуту сцену можемо тумачити као сликовити пример функционисања трауме и, у овом случају, немогућег превазилажења трауме која потискивањем постаје све већа и снажнија. Траума ненаданог рођења детета надовезала се на трауму смрти мртве драге док изнад свега тога лебде речи из Морелине клетве, речи које трајно субјект чине напетим и оптерећеним. Траума/трауме не успевају бити превазиђене. Стога, на примеру приповетке Мореле, тематизације мртве драге јесте дата као визија ње са јасним и препознатљивим обрисима. До „привида поновног сједињавања песничког субјекта са мртвом драгом" (VLADUŠIĆ 2009: 17) долази уколико посматрамо његову тежњу за оприсутњавањем мртве драге у лику живе кћерке. Међутим, важно је подвући да је та жеља за синтезом са мртвом драгом, Морелом, потребна и жељена више због страха да не дође до остваривања изречене клетве него због жеље за поновним и истинским љубавним јединством са драгом каквом се јунак у Гаврану нада.

Процес (ре)конфигурације мисли о мртвој драгој неумитно има своје тежиште у прошлости, у кобним реченицама Мореле. Зато није могуће доспети до психичке прогресије јер је све утемељено у непревазиђеним траумама. Садашњост опседнута прошлошћу типична је појава за конфигурацију наратива о трауми и трауматизму (уп. MATOVIĆ 2020: $50)$, али на Поовом примеру, и садашњост и будућност остају опседнуте прошлошћу.

\section{3. Ото Хорват, Сабо је стао}

Сабо стоји у трауми - преговор са траумом посредством дискурса

Роман Сабо је стао аутора Ота Хорвата објављен је 2014. године и заснива се на „мотиву мртве драге и орфичком покушају враћања ње из Хада" (ВАВIĆ 2014: 72). Реч је о хронолошки нелинеарној исповести супруга након смрти супруге A. ${ }^{10}$, оболелој од неизлечиве болести. Jунак „романа сеанси” (JOCIĆ 2015: 177), Саша Сабо, евоцира успомене задирањем у најдаље пределе сећања и тим понирањем у хронологију љубавног односа, подвргава се својеврсној самотерапији превазилажења губитка. Већ из наслова поглавља, уочава се њихова симболичност: наликујући на психотерапијска питања ${ }^{11}$, могуће је да роман схватимо као пут излечења трауме. Ово терапијско приповедање пропраћено је Сабоовим 10 Јоцић (2015: 178) у имену мртве драге, А., препознаје реч Алеф. Причом о А.: „дивинизација драге постаје романтично-библиотекарска".

11 Наслови поглавља: „Почните, господине Сабо!”, „На ком књижевном мотиву се базира Ваш живот?”, „У коју теглу заборава бисте да се завучете?”, „Бојите се да ћете је заборавити, ако наставите да живите?”, „Да ли је ово све за данас, господине Сабо?”, итд. 
исповестима и сталним самоокривљивањем: себе ће у пар наврата назвати издајицом („Ја, издајица. Једини. За вјек и вјеков.” (HORVAT 2014: 61)). Приповедање је сачињено од приповедачког ја, анализирајућег ти и свезнајућег лица. Сабо се, дакле, уписује у текст троструко: као говорник, саговорник и посматрач.

У наслову романа - Сабо је стао - препознајемо симболичност затечености у тренутку и то затечености у тренутку смрти драге, затечености у трауми. Њиме је упућено на трауматски положај субјекта који је немогућност (даљег) наставка. Стога, приповедање из те тачке је једино шта је преостало пошто је све остало (не)стало. Ако јунак романа, Саша Сабо, стоји у тренутку трауматског губитка, јасно је да је то стационарно стање, а да је оно уско повезано са наративом који се даје као покушај прекида тог стања, као покушај наставка, као прекид стајања. Дакле, читав роман јесте покушај превазилажења затечености у трауми уз помоћ дискурзивног апарата - уз помоћ приповедања.

Фројд је потенцирао лечење трауме причом (talking cure), наративизацијом сећања и позиционирањем актуелних жеља у односу на ту наративизацију (уп. MATOVIĆ 2020: 101). Сабоова наративизација сећања има алегоричну струкутуру: мртва драга је објект продуженог сећања субјекта - хиперсећања (уп. VLADUŠIĆ 2009: 317). То значи да би Хорватова тематизација мотива мртве драге била она у којој се субјект не заварава у погледу одвојености од ње (уп. VLADUŠIĆ 2009: 17), али неисцрпно наставља да је опева, да о њој пише. Дискурзивним напорима тежи се одржању тог сећања, поновним рекреирањем слике ње, Сабо преминулу А. наративно оприсутњује. Служећи се механизмом понирања у хронологију односа ${ }^{12}$, Сабоов ток сећања постаје нехронолошки лавиринт: прича започета његовим одласком са очевим кофером у руци преплиће се са причом о њиховој исељеничкој љубави. Истицање некадашњег учесталог просторног лутања (боравак у Берлину, Будимпешти, Новом Саду, Мађарској, Немачкој, Италији) потребно је како би се контрастирало садашњем тренутку стајања. Само је преостало сећање из ког Сабо црпи сав садржај у покушају да врати и оживи све тренутке са А. Кроз хиперпамћење остварено је конзервирање мртве драге (уп. VLADUŠIĆ 2009: 318), а ретроспектива је та која омогућава поновно покретање сећања зарад покушаја превазилажења трауме губитка. У ретроспективи као механизму се крије потреба за тачним именовањем ствари које би требало да доведу до превазилажења те трауме: дакле, субјект мора да прихвати и вербално потврди да је А. умрла.

12 И у приповеци Морела постоји механизам понирања у хронологију где субјект из садашњег тренутка прича о прошлости и смрти супруге. Разлика је то што је приповедање у Морели правилног хронолошког следа док смо у роману Сабо је стао подвргнути трагању за хронологијом: преплиће се далека и блиска прошлост са садашњошћу. 
Ту борбу са превазилажењем трауме показаћемо на следећим примерима. Сабо говори: „по читавом стану си сада раширио њене фотографије већег формата које си направио након што је." (HORVAT 2014: 47), потом ,али не умеш да престанеш да причаш са њом, иако.”(HORVAT 2014: 47). Сабо када говори о смрти А., не успева да доврши реченицу. Зато је потребна вербализација и дискурзивно именовање осећања јер онда када говором човек постане свестан својих мисли и свог стања, тек ће тада моћи да прихвати реалност. Назовимо то говором, исповедањем, самотерапијом, обраћањем себи или обраћањем читаоцима, психотерапијском сеансом, туговањем - не може се узмаћи закључку да је једини делотворни преговор у Сабоовом случају вербализација, одн. говор о трауми, именовање ње.

Сабо ће на крају романа коначно изговорити „јер твоја А. је умрла и никаква реченица [...] ништа не може да ти је врати нити да ти ублажи бол због тога." (HORVAT 2014: 78). Дакле, сврха свег текста пре ове реченице била је борба са самим собом да би се доспело до прихватања да се А. неће вратити и да неће престати да боли. После њених речи „Благо теби, ти ћеш живети.” (HORVAT 2014: 89) и смрти, психички свет субјекта јесте и остаје дубоко уздрман и оптерећен непрестаном кривицом. Од окривљивања себе и називања издајицом неће одустати јер чињеница да је био присутан у њеном животном гашењу, а да је био толико беспомоћан док је умирала, наводи га на константно самоокривљивање. Једино избављујуће у јунаковој трауми је наратив, вербализација и ретроспектива, то су кључни механизми којима се Саша Сабо користи како би помогао себи.

\section{4. Закључак}

Трауматска стања све тројице вербализована су што значи да је примарни механизам којим се служе механизам дискурзивне природе. Дискурзивни механизам заснива се првенствено на именовању ствари, односно, на покретању трауматске тачке на ма који начин. Дискурзивно покренути тему своје мртве драге први је корак у сусретању са извориштем трауме. Потенцијал дискурзивног механизма је најефектније дат у роману Сабо је стао јер је ово роман исповести трауматског стања и као такав има форму психотерапијске сеансе (питања, одговори и смена приповедачких лица).

У сва три дела, успостављени механизми превазилажења губитка су и вид борбе са доживљеном трауме. Траума претходи механизмима, али шта осим трагедије претходи трауми? Трауми претходи сећање, али је и (пост)трауми потребно присећање. Сећање, или прецизније речено, памћење пре трауме другачијег је садржинско-структурног склопа јер 
није оптерећено смрћу ни траумом. Након трауматског „конкретног догађаја” (KALI TAL 1996: 457 према MATOVIĆ 2020: 84), (при)сећање постаје психички напрегнуто зарад рекреирања и реконструисања старих сећања. Сећање после смрти драге постаје њоме преоптерећено и узрочно-последично зависно од ње као од женског бића. Женско биће, жена као драга, извор је сећања свих поменутих јунака. Оног тренутка када предмет сећања бива усмрћен, када ишчезне из физичке присутности, сећање подлеже трауматском шоку и тежи да интензификује и вештачки, по сваку цену, (ра)створи сећање о њој. Мртва драга постаје извор (посттрауматског) сећања кроз који се даје живот једном наративу - поеми, приповеци, роману - а то је ваљани показатељ како се феномен сећања опире директном описивању и како може одвести у сликовитост (уп. ASMAN 1999: 121). Онда када психичка свест постане свесна бесповратности свог некадашњег живог предмета сећања, она тежи да поврати ишчезло у све(с)т - у првом реду, јунак Гаврана неутешно жели да су ти шумови њено поновно присуство; јунак Мореле не остаје на жељи попут јунака у Гаврану, његова психичка свест преминули предмет сећања несвесно оприсутњује у живој кћерци услед немогућности превазилажења траума; Саша Сабо понирањем у сећања, мртву А. наративно васкрсава све до тачке када је визуелно и просторно не оприсутни у виду увећаних фотографија. Уочавамо да је тело као место женског бића простор знака који омогућава сећање. У Гаврану се жели да до Ленорине физичке појаве дође, у Морели је тело као простор знака усложењено јер физичке и интелектуалне особине мртве драге јунак пројицира на тело кћерке тежећи да у њој оприсутни мртву супругу. У роману Сабо је стао тело као место женског бића, а које је простор знака који омогућава сећање, покренуто је у пар наврата кроз конкретне реминисценције на њене физичке појаве у простору пре смрти. Међутим, долази до екстремног деловања тог простора знака јер Саша Сабо осим што након трауме вештачки ствара њено тело у простору израдом увећаних фотографија које качи по зидовима, он тиме несвесно жели да омогући, продужи сећање и спречи заборав. Опристуњивање је потребно да не би дошло до заборава, а да би се истовремено покренуло сећање. Дакле, вештачко рекреирање простора знаком тела, односно, њено оприсутњивање у простору уско је повезано са проблемом сећања које и он сам доводи у питање. Тај механизам оприсутњивања вид је механизма који служи као покушај превазилажења трауме, а заправо их само уводи у још јаче психичке потресе јер иако се тежи том оприсутњивању, до њега никад истински не долази већ се оно само вештачки иницира. Разочарење јер је оприсутњивање само привремена илузија, јунаке дела не одводи директно превазилажењу трауме него судару са реалношћу и отрежњујућој спознаји смрти у којој се крије 
једина истина о бесповратности мртве драге.

\section{Цитирана литература}

ASMAN 1999: ASMAN, Alaida, O metafori sećanja, u: Reč: časopis za književnost i kulturu, br. 56(2), 121-136, 1999.

BABIĆ 2014: BABIĆ, Dragan, Ja, Izdajica, In aeternum, ili „Kako pretvoriti katastrofu u umetnost?", u: NM: Nova misao: časopis za savremenu kulturu Vojvodine, br. 28 (jul-avg 2014), str. 72, 2014.

BERGSON 1927: BERGSON, Henri, Materija i memorija, Beograd: G. Kon, 1927. [orig.] БЕРГСОН, Хенри, Материја и меморија, Београд: Г. Кон, 1927.

FROJD 2006a: FROJD, Sigmund, S one strane principa zadovoljstva, u: S. Frojd, Psihologija mase i analiza ega, Beograd: Fedon, 2006.

FROJD 2006b: FROJD, Sigmund, Kompletan uvod u psihoanalizu, Podgorica: Nova knjiga, 2006.

JOCIĆ 2015: JOCIĆ, Miloš, Post-ljubav, post-smrt, u: Polja: mesečnik za umetnost i kulturu, God. 60, br. 491, Novi Sad: Progres, 177-179, 2015. [orig.] ЈОЦИТ, Милош, Пост-љубав, пост-смрт, у: Поља: месечник за уметност и културу, Год. 60, бр. 491, Нови Сад: Прогрес, 177-179, 2015.

MATOVIĆ 2020: MATOVIĆ, Tijana, Trauma i sećanje u prozi Kazua Išigura [doktorska disertacija], Kragujevac: Т. Matović, 2020. [orig.] МАТОВИЋ, Тијана, Траума и сећање у прози Казуа Ишигура [докторска дисертација], Крагујевац: Т. Матовић, 2020.

PO 2006b: PO, Edgar Alan, Filozofija kompozicije, u: E. A. Po, Gavran, Beograd: Rad, 68-82, 2006.

ŠEVALIJE, GERBRAN 2004: ŠEVALIJE, Žan; GERBRAN, Alen, Rečnik simbola: mitovi, snovi, običaji, postupci, oblici, likovi, boje, brojevi, Novi Sad: Stylos, 2004.

VLADUŠIĆ 2009: VLADUŠIĆ, Slobodan, Ko je ubio mrtvu dragu?, Beograd: Službeni glasnik, 2009. [orig.] ВЛАДУШИЋ, Слободан, Ко је убио мртву драгу?, Београд: Службени гласник, 2009.

\section{Извори}

HORVAT 2014: HORVAT, Oto, Sabo je stao, Zrennjanin: Novi Sad: Agora, 2014. PO 1996: PO, Edgar Alan, Ukradeno pismo i druge priče (prir. D. Jakovljević), Novi Sad: Svetovi, 1996.

PO 2006a: PO, Edgar Alan, Gavran (prevod Kolja Mićević, str. 39-47), Beograd: Rad, 2006. 
Aleksandra V. Čebašek

THE MECHANISMS OF NEGOTIATIONS WITH A LOSS: TRAUMA OF THE DEAD BELOVED IN THE RAVEN AND MORELLA BY EDGAR ALLAN POE AND IN THE NOVES SABO HAS STOPPED BY OTO HORVAT

The common thread which connects Morella and The Raven by Edgar Allan Poe and the novel Sabo has stopped by Oto Horvat is the theme of a dead beloved which is the cause of trauma for the three heroes. Firstly, we will discuss trauma as a psychological state, then we will point out the motif of a dead beloved which is simultaneously one of the most beautiful and the most tragic motifs in literature. The paper will examine the traumatic and post-traumatic states of the subjects, that is, it will investigate which and what mechanisms of negotiations with a loss exist in the mentioned works, what purpose they serve and whether they enable deliverance from trauma for the subjects. Therefore, we will indicate whether and in what way it is possible to overcome the trauma in the mentioned works. Dead beloveds - Lenore, Morella and A. - they are presented differently and their deaths are thematized in different ways. In every possible way, the subjects try to keep the dead beloved alive, at least in the text, at least discursively, at least in memory. The aim is to point out the principles of functioning of (and attempts to overcome) trauma, from the mildest example, The Raven, to the most extreme, the novel Sabo has stopped, in which the subject became completely empathetic with trauma. In addition to the thematization of the dead beloved, Morella will also serve as an example of how the unsurpassed traumas can be devastating and tragic for the subject due to their accumulation.

Keywords: dead beloved, trauma, The Raven, Morella, Edgar Allan Poe, Sabo has stopped, Oto Horvat, mechanisms of negotiations, psychoanalysis 